\title{
Does the Composition of the Stones Counts in Patients Who Underwent Percutaneous Nephrolithotomy?
}

\author{
CIPRIAN TODEA-MOGA ${ }^{1,2}$, ORSOLYA MARTHA ${ }^{1,2}$, IOAN SCARNECIU ${ }^{3,4}$, CAMELIA CORNELIA SCARNECIU 3,4 , LAURIAN MAXIM ${ }^{4}$, \\ COSTIN VLAD ANASTASIU ${ }^{3}$, ALEXANDRU BANUTA ${ }^{4}$, VERONICA GHIRCA ${ }^{1,2 *}$, DAN LIVIU DOREL MISCHIANU ${ }^{5,6}$, \\ DANIEL PORAV-HODADE ${ }^{1,2}$ \\ 'Urology Clinic, Mures County Hospital, 50 Dr. Gheorghe Marinescu Str., 540136, Targu Mures, Romania \\ ¿University of Medicine, Pharmacy, Science and Technology, 38 Gheorghe Marinescu Str., 540139, Targu Mures, Romania \\ 3University of Medicine and Pharmacy Transilvania, 56 Nicolae Balcescu Str., 500019, Brasov, Romania \\ ${ }^{4}$ Clinical Emergency County Hospital, 25-27 Bucuresti Road, 500326, Brasov, Romania \\ ${ }^{5}$ Carol Davila University of Medicine and Pharmacy, 8 Eroii Sanitari Str., 050474, Bucharest, Romania \\ ${ }^{6}$ Academy of Romanian Scientists, 54 Splaiul Independentei, 030167, Bucharest, Romania
}

\begin{abstract}
The aim of this study is to highlight the importance of percutaneous nephrolithotomy (PCNL) in the treatment of kidney stones with different chemical composition. We included in this study 200 patients with kidney stones who underwent PCNL. In most of the cases the stones were composed by calcium, usually calcium oxalate followed by struvite and uric acid component. The stones were mostly localized in the renal pelvis (142), inferior calyx (46) and ureteropelvic junction (4) and 28 cases with staghorn stones. Intraoperative complications were: migrating fragments (22\%), hemorrhage (12\%), lesions of the renal pelvis and difficulties of percutaneous access or dilatation (6\%). The postoperative complications were: bleeding (20\%), obstruction caused by stone fragments (22.5\%), hydronephrosis (18\%), fistula (13\%). The average length of hospitalization after PCNL was $5.58+/-2.69$ days SD. Stone-free rate was: $77.5 \%$. PCNL is a safe and effective method of treatment for large and complex stones. Intra and postoperative complications after PCNL are not influenced directly by the chemical composition of the stones. It is important to evaluate the chemical composition of the stones in order to establish the treatment management and to recommend a proper conservative treatment in order to prevent the recurrence of the disease.
\end{abstract}

Keywords: PCNL, renal stone, Steghorn calculi, postoperative complications.

Kidney stone is a common and painful condition and represent a major cause of morbidity with a prevalence of approximately $10 \%$ in men and $5 \%$ in women [1].

In the United States, European countries and Southeast Asia, the prevalence of lithiasis has doubled over the past thirty years [2]. In Caucasian males the incidence of kidney stones is higher [3] and rises to approximately 3 out of 1,000 cases in a year in people aged 40 - 60 years old, and then decrease [4]. In females, the incidence rate is higher after 20 years old and decrease after the age of 50 [3].

The increased incidence of lithiasis is associated with race, ethnicity, residence, improved living standards and has become recognized as a risk factor for chronic kidney disease [5,6], coronary artery disease [7,8], hypertension [9], dyselectrolytemias $[10,11]$, type 2 diabetes and systemic inflammatory response syndrome [12]. Without medical treatment lithiasis can become a chronic disease in 10 years, with an approximately $50 \%$ recurrence rate [12].

The risk factors for developing kidney stones can be classified into three groups: endogenous causes (metabolic dysfunctions, endocrine diseases like hyperparathyroidism, tumors [13], gastric hypoacidity, etc.), renal causes (kidney dysfunction, tubular disorders), and post-renal causes (malformations and urinary tract obstruction by extrinsec compresion or invasion [14-17], bladder pathology $[18,19]$ or subvesical obstruction $[20,21]$, post-surgical procedures [22,23], bacterial infections) [24].

Percutaneous nephrolithotomy (PCNL) represents a surgical treatment method that allows the fragmentation and extraction of large kidney stones. This procedure has a higher morbidity than Extracorporeal Shock Wave Lithotripsy (ESWL) or ureteroscopy and it is only used in case of complex stones, exceeding $2-2.5 \mathrm{~cm}$ [25]. The progress of minimally invasive treatment alternatives and the development of instruments for ureteroscopy assure the achievement of higher performances, especially in both ureteral and renal lithiasis [26-28].

\section{Experimental part}

Material and method

We included in this study 200 patients with different chemical composition of renal stones who were surgical treated by performing percutaneous nephrolithotomy (PCNL) over a period of 10 months (June 2016- April 2017).

Inclusion criteria and the classification of the obtained data in this study were:

- patients older than 18 years with renal stones located in the lower calyx, renal pelvis and ureteropelvic junction.

- the size of the kidney stone e" $20 \mathrm{~mm}$; (stone size was calculated by taking into consideration the sum of the maximum diameters) and multiple lithiasis.

- the chemical composition of the stones

We don't have all the data of the patients concerning the chemical composition of the stone (mostly from financial reasons), but in most of the cases the stones were composed by calcium, usually calcium oxalate followed by struvite and uric acid component.

The protocol used for the selection of patients consisted of:

- history;

- abdominal ultrasound;

- intravenous pyelogram (IVP) and/or computed tomography (CT);

- complete blood count, biochemical, coagulation parameters, urine analysis. 


\section{Statistical analysis}

We used the Statistical Package for Social Sciences (SPSS, version 22, Chicago, IL, USA) to perform statistical analysis. Data were classified as nominal or quantitative variables. The frequencies of nominal variables were compared to a chi-square or Fisher test. The level of statistical significance was set at $p<0.05$.

\section{Results and discussions}

Through the total 200 investigated patients, 106 (53\%) were man and 94 women (47\%). Regarding their age, we observed that most of the patients were under 70 years old (178 cases) and 22 of the patients were older than 70 years. The mean age of the patients was 53.65 years old $(+/-12.18$ Standard Deviation- SD) with limits between $25-81$ years old. Concerning the age, the prevalence ofthe kidney stones is more rare before age 20, being more frequent after age 40 and 60 [29]. It was considered that the urinary saturation of calcium oxalate and brushite is lower in women then in men until age 50 [29]. This can be related with the modifications of urinary and serum oxalate concentration which can be increased by androgens and decreased by estrogens, found in an experimental rat model [29].

The stones were mostly localized in the renal pelvis (142), inferior calyx (46) and ureteropelvic junction (4) and 28 cases were with staghorn stones. The renal stones were larger than $2 \mathrm{~cm}$ in $76 \%$, less than $2 \mathrm{~cm}$ in $13 \%$ of the cases and $11 \%$ of the patients had multiple lithiasis.

The most common component of urinary stones is calcium, which can be found in $75 \%$ of stones [29]. The most frequent chemical content of the stones is calcium oxalate (60\% of the cases), mixed calcium oxalate and hydroxyapatite (20\%); and brushite (2\%) [30]. Uric acid and struvite (magnesium ammonium phosphate) stones can be found in $10 \%$ of the cases, while cystine stones are more rare (1-3\%) [30].

Heat exposure and dehydration can determine lower urine volumes, modifications of $\mathrm{pH}$, higher level of acid uric that represent risk factors for stone formation in $8 \%$ of the patients who are exposed to those risk factors, compared to patients who are not exposed (0.9\%) [31].

The weight and body mass index represents risk factors for stones formation in majority those who contain calcium in $80 \%$ of the cases [32]. Obesity determine insulin resistance, hyperinsulinemia and metabolic syndrome that can increase the risk of calcium stone formation [33]. High body mass index is associated with increased uric acid and oxalate excretion and can determine modifications in endogenous oxalate synthesis that can favor the formation of calcium oxalate stones [34,35].

The formation of calcium oxalate stones can be influenced also by family history, urine volume, urinary concentration of calcium, oxalate, uric acid and citrate, diet, medication, etc. [36-38]. A diet based on purine intake represent a risk factor for uric acid production which can lead to calcium oxalate stone formation [39,40].

Hypertension represents also a risk factor for stone formation that can be explained through the increased urinary calcium excretion, having a prevalence of $23.3 \%$ of the patients compared with $13,4 \%$ of the cases with normal tension [41,42].

A high fluid intake, dehydration and the mineral and electrolyte content of water can influence prevalence of lithiasis [29].

Urinary tract infections are assessed with stones formation prevalentby magnesium ammonium phosphate composition ( $\left.\mathrm{MgNH}_{4} \mathrm{PO}_{4} .6 \mathrm{H}_{2} \mathrm{O}\right)$, calcium phosphate or carbonate apatite composition ( $\left.\mathrm{Ca} 10\left[\mathrm{PO}_{4}\right] 6 . \mathrm{CO}_{3}\right)$ [29].
The most common urease-producing pathogens that are associated with infectious stones are Proteus, Klebsiella, Pseudomonas, and Staphylococcus [29]. Kidney stones that are associated with infections are in most of the cases metabolic stones, composed of calcium phosphate or calcium oxalate, being reported with a prevalence of $35 \%$ of the cases [42]. Bacteria can produce modifications of the $\mathrm{pH}$, stimulate the production of proteins into the matrix or struvite crystal precipitation that can influence the stone formation process [43-45].

The main risk factors for uric acid stone formation can be low urine volume, low value of $\mathrm{pH}$ and hyperuricosuria [29], but also uric acid crystal adhesion to kidney cells and inhibitors like glycosamino-glycans can increase the risk of uric acid stone formation [46].

The evaluation of the chemical composition of the stones is very important and lead us to establish a proper treatment management (conservative and/or surgical) and to prevent the recurrence of the disease. Chemical stone analysis is a qualitative method of determining the chemical composition of stones [47]. The modern methods developed, include X-ray diffraction, infrared spectroscopy, optic polarizing microscopy, scanning electron microscopy and others [47]. In all the cases included in our study we performed surgical treatmentpercutaneous nephrolithotomy (PCNL).

Regarding the intraoperative complications in most of the cases (44) was the migration of stone or fragments, hemorrhage in 24 cases, impossibility of percutaneous access of the inferior calyx or the inability or difficulty of dilatation of the nephrostomy tract, in 10 cases, difficulty of ureteral catheterization in 6 cases, lesions of the ureteral orifice in 4 cases and lesions of the renal pelvis in 2 cases. The chemical composition of the stones was not correlated with the intraoperative complications, $p>0.05$.

The most frequent postoperative complications observed in our study were residual fragments in 45 cases, hemorrhage in 40 cases, postoperative hydronephrosis in 36 cases and lumbar fistula in 26 cases, after the migration of a fragment into the ureter. The chemical composition of the stones was not correlated with the postoperative complications, $p>0.05$.

The average length of hospitalization after the surgery was 5.58 days $(+/-2.69$ standard deviation). In most of the cases the cause of the prolonged hospitalization were haematurria and the obstructed complications (hydronephrosis, residual fragments, fistula).

The stone-free rate was established after the surgery according to the abdominal ultrasound result and radiological examination, which proved to be $77.5 \%$.

\section{Conclusions}

PCNL is a safe and effective method of treatment for large and complex stones .

Intra and postoperative complications may occur without being influenced directly by the chemical stones' composition and this was not a decisive factor in the choice of surgical treatment.

It is important to evaluate the chemical composition of the stones in order to establish the treatment management and to recommend a proper conservative treatment in order to prevent the recurrence of the disease.

\section{References}

1.STAMATELOU, K.K., FRANCIS, M.E., JONES, C.A., NYBERG, L.M., CURHAN, G.C., Kidney Int, 63, no. 5, 2003, p.1817.

2.SAKHAEE, K., MAALOUF, N.M., SINNOTT, B., J. Clin. Endocrinol. Metab., 97, no. 6, 2012, p.1847. 
3.LIESKE, J.C., PENA DE LA VEGA, L.S., SLEZAK, J.M., BERGSTRALH, E.J ., LEIBSON, C.L., HO, K.L., GETTMAN, M.T., Kidney Int, 69, no. 4, 2006, p.760.

4.HIATT, R.A., DALES, L.G., FRIEDMAN, G.D., HUNKELER, E.M., Am. J. Epidemiol., 115, no. 2, 1982, p. 255.

5.NICULAE, A., PERIDE, I., VINEREANU, V., RADULESCU, D., BRATU, O.G., GEAVLETE, B.F., CHECHERITA, I.A., Rom. J. Morphol. Embryol., 58, no. 3, 2017, p. 1065.

6.NICULAE, A., PERIDE, I., MARINESCU-PANINOPOL, A., VRABIE, C.D., GINGHINA, O., JECAN, C.R., BRATU, O.G., Rom. J. Morphol. Embryol., 57, no. 2, 2016, p. 591.

7.MANEA, M., MARCU, D., PANTEA STOIAN, A., GAMAN, M.A., GAMAN, A.M., SOCEA, B., NEAGU, T.P., STANESCU, A.M.A., BRATU, O.G., DIACONU, C.C., Rev. Chim. (Bucharest), 69, no. 11, 2018, p. 4180.

8.TICA, O.A., TICA, O., ANTAL, L., HATOS, A., POPESCU, M.I., PANTEA STOIAN, A., BRATU, O.G., GAMAN, M.A., PITURU, S.M., DIACONU, C.C., Farmacia, 66, no. 6, 2018, p. 972.

9.DIACONU, C.C., DRAGOI, C.M., BRATU, O.G., NEAGU, T.P., PANTEA STOIAN, A., COBELSCHI, P.C., NICOLAE, A.C., IANCU, M.A., HAINAROSIE, R., STANESCU, A.M.A., SOCEA, B., Farmacia, 66, no. 3, 2018, p. 408.

10.DIACONU, C.C., STANESCU, A.M.A., PANTEA STOIAN, A., TINCU, R.C., COBILINSCHI, C., DRAGOMIRESCU, R.I.F., SOCEA, B., SPINU, D.A., MARCU, D., SOCEA, L.I., BRATU, O.G., Rev. Chim. (Bucharest), 69, no. 6, 2018, p. 1367.

11.DIACONU, C.C., MANEA, M., IANCU, M.A., STANESCU, A.M.A., SOCEA, B., SPINU, D.A., MARCU, D., BRATU, O.G., Rev. Chim. (Bucharest), 69, no. 5, 2018, p. 1071.

12.NEMES-NAGY, E., MAIER, A., MAN, A., Annals of RSCB, 10, no. 1, 2015, p. 68.

13.BRATU, O., MISCHIANU, D., SPINU, D., BARLA, R., HOARA, P., CONSTANTINOIU, S., Chirurgia (Bucur), 108 ,no. 1, 2013, p. 26. 14.BRATU, O.G., CHERCIU, A.I., BUMBU, A., LUPU, S., MARCU, D.R., IONITA RADU, F., MANEA, M., FURAU, C., DIACONU, C.C., MISCHIANU, D.L.D., Rev. Chim. (Bucharest), 70, no. 1, 2019, p. 190.

15.MARCU, R.D., SPINU, A.D., SOCEA, B., BODEAN, M.O., DIACONU, C.C., VASILESCU, F., NEAGU, T.P., BRATU, O.G., Rev. Chim. (Bucharest), 69, no. 4, 2018, p. 823.

16.BRATU, O.G., MARCU, R.D., SOCEA, B., NEAGU, T.P., DIACONU, C.C., SCARNECIU, I., TURCU, F.L., RADAVOI, G.D., BRATILA, E., BERCEANU, C., SPINU, A.D., Rev. Chim. (Bucharest), 69, no. 7, 2018, p. 1813.

17.TATARU, A.-L., FURAU, G., AFILON, J., IONESCU, C., DIMITRIU, M., BRATU, O.G., TIT, D.M., BUNGAU, S., FURAU, C., J. Clin. Med., 8, no. 1, 2019, E96; https://doi.org/10.3390/jcm8010096.

18.STANIMIR, M., CHIUTU, L.C., WESE, S., MILULESCU, A., NEMES, R.N., BRATU, O., Rom. J. Morphol. Embryol., 57, no. 2 (suppl), 2016, p. 849.

19.BODEAN, O., BRATU, O., BOHILTEA, R., MUNTEANU, O., MARCU, D., SPINU, D.A., VACAROIU, I.A., SOCEA, B., DIACONU, C.C., FOMETESCU GRADINARU, D., CIRSTOIU, M., Rev. Chim. (Bucharest), 69, no. 6, 2018, p. 1411.

20.RADAVOI, G.D., PRICOP, C., JINGA, V., MATES, D., RADOI, V.E., JINGA, M., URSU, R.I., BRATU, O.G., MISCHIANU, D.L., IORDACHE, P., Rom. J. Morphol. Embryol., 57, no. 2, 2016, p. 467.

21.SPINU, D., BRATU, O., MARCU, D., MISCHIANU, D., HUICA, R., SURCEL, M., MUNTEANU, A., SOCEA, B., BODEAN, O., URSACIUC, C., Rev. Chim. (Bucharest), 69, no. 3, 2018, p. 645.
22.SCARNECIU, I., ANDREI, C., SCARNECIU, C., LUPU, A.M., BRATU, O.G., LUPU, S., Urology Journal, 15, no. 5, 2018, p. 297.

23.BRATU, O., MISCHIANU, D., CONSTANTINOIU, S., Chirurgia (Bucur), 108, no. 2, 2013, p. 250.

24.PARMAN MALVINDER, S., BMJ, 328, no. 7453, 2004, p.1420.

25.NOVICK, A.C., JONES, J.S., Chapter 6: Renal Calculus Disease, Humana Press, 2006 p. 67.

26.TISELIUS, H.G., ACKERMAN, D., ALKEN, P., BUCK, C., CONORT, P., GALLUCCI, M., European Association of Urology, 2006, p.1.

27.SPINU, A.D., MARCU, R.D., SOCEA, B., DIACONU, C.C., SCARNECIU, I., SCARNECIU, C., BODEAN, O.M., DRAGOMIRESCU, R.I.F., STANESCU, A.M.A., MISCHIANU, D.L.D., BRATU, O.G., Rev. Chim. (Bucharest), 69, no. 8, 2018, p. 2061.

28.SCARNECIU, I., BRATU, O.G., COBELSCHI, C.P., NECULOIU, C.D., SCARNECIU, C.C., LUPU, S., BRINZA, A., MARCU, D., SOCEA, B., MAXIM, L., Rev. Chim. (Bucharest), 69, no. 12, 2018, p. 3406.

29.PEARLE, M., LOTAN, Y., Campbell-Walsh Urology, $10^{\text {th }}$ edition, 45, p. 1257.

30.PEARLE, M.S., PAK, Y.C., International yearbook of nephrology,1996, p. 69.

31.HOLMES, R.P., ASSIMOS, D.G., Urol Res, 32, no. 5, 2004, p. 311.

32.COE, F.L., PARKS, J.H., ASPLIN, J.R., N Engl J Med, 327, no. 16, 1992, p. 1141.

33.ABATE, N., CHANDALIA, M., CABO-CHANAVJ R, MOEOW., SAKHAEE, K., Kidney Int, 65, no. 2, 2004, p. 386.

34.COE, F.L., KAVALACH, A.G., N Engl J Med, 291, no. 25, 1974, p. 1344.

35.LEMANN, J. JR., PLEUSS, J.A., WORCESTER, E.M., HORNICKE, L., SCHRAB, D., HOFFMANN, R.G., Kidney Int., 49, no. 1, 1996, p. 200.

36.COE, F., PARKS, I., Year Book Medical, 1988, p.1

37.WYNGAARDEN, J., J ELLEY, W., 5th Ed., 1983, p 1043

38.BUMBU, A., PASCA, B., TIT, D. M., BUNGAU, S., BUMBU, G., Farmacia, 64, no. 3, 2016, p. 419.

39.ABDEL-DAIM, M.M., ZAKHARY, N.I., ALEYA, L., BUNGAU, S.G., BOHARA, R. A., SIDDIQI, N.J., Oxid. Med. Cell. Longev., 2018, 2018, ID 2098123. https://doi.org/10.1155/2018/2098123

40.SOCEA, L.I., VISAN, D.C., BARBUCEANU, S.F., APOSTOL, T.V., BRATU, O.G., SOCEA, B., Rev. Chim. (Bucharest), 69, no. 4, 2018, p. 795.

41.CAPPUCCIO, F.P., STRAZZULLO, P., MANCINI, M., BMJ, 300, no. 6734, 1990, p. 1234.

42.BORGHI, L., NOUVENNE, A., MESCHI, T., Nephrol Dial Transplant, 27, no. 11, 2012, p. 3982.

43.STOICESCU, M., BUNGAU, S., TIT, D.M., MUTIU, G., PURZA, L., IOVAN, C., POP, O.L., Rom. J. Morphol. Embriol., 58, nr. 4, 2017, p. 1429.

44.RADULESCU, A., MADAN, V., AUNGURENCI, A., BRATU, O., FARCAS, C., DINU, M., MISCHIANU, D., Romanian J ournal of Military Medicine, 118, no. 3, 2015, p. 20.

45.SPINU, D., BRATU, O., POPESCU, R., MARCU, D., RADULESCU, A., MISCHIANU, D., Romanian J ournal of Military Medicine, 118, no. 3, 2015, p.12.

46.PAK, C., SAKHAEE, K., PETERSON, R., POINDEXTER, J., FRAWLEY, W., Kidney International, 60, no. 2, 2001, p. 757.

47.BASIRI, A., TAHERI, M., TAHERI, F., Urol J, 9, no. 2, 2012, p. 445

$\overline{\text { Manuscript received: } 11.08 .2018}$ 